\title{
An economic Study the Resource Structure and Levels of Investment on the Sample Farms in District of Mau Nath Bhanjan (U.P.), India
}

\author{
Kuldeep Maurya ${ }^{1 *}$, J. Rai ${ }^{1}$, Sharad Yadav', Ram Singh Yadav ${ }^{2}$ and \\ Arun Kumar Rajbhar ${ }^{3}$ \\ ${ }^{1}$ Department of Agricultural Economics \& Statistics, College of Agriculture, C. S. Azad \\ University of Agriculture \&Technology, Kanpur (208002), India \\ ${ }^{2}$ Department of Agricultural Economics, N.D.U.A. \& T. Kumarganj, Ayodhya (224229) Uttar \\ Pradesh, India \\ ${ }^{3}$ School of Agricultural, Lovely Professional University, Panjab (14441), India \\ *Corresponding author
}

\section{A B S T R A C T}

The study of resource structure and level of investment forms the basis for successful farm planning, farm growth and expanding economic opportunities on farms. This calls for an intensive enquiry of the resources and the extent to which advances in farm technology have been adopted by the farmers. The average size of operational farm holding came to 0.77 hectare. It was 0.47 hectare for marginal farms, 1.60 hectare for small farms and 3.33 hectares for medium farms. The average size of family of the sample farms came to 7.14 members. It was a little small being 5.70 members on marginal farms as compared to 6.81 members on small farms and 7.00 members on medium farms. The average investment in fixed capital including land on per farm household basis came to Rs. 145294.54, which varied from Rs. 71770.74 on marginal farms to Rs. 348515.20 on small farms and further to Rs. 778670.55 per farm on medium farms. The analysis of cropping pattern showed that wheat accounted for the highest area being 42.63 per cent, followed by paddy 37.80 per cent, rapeseed and mustard 8.30 per cent, maize 3.03 per cent and arhar 2.61 per cent and to total cropped area. The main source of irrigation in the area were tube wells and canal which on an average irrigated 96.70 per cent and 3.30 per cent of the total irrigated area. The average intensity of cropping on farms came to 170.50 per cent which was a little lower being 169.60 per cent on marginal farms and a little higher 171.77 on medium farms. District Mau of Eastern U.P. has an important place in terms of fertility and agricultural advancement in India. The land of this part is Loamy which is most fertile. The total geographical area of the district is 171624.00 ha. out of which 560.00 ha., 2504.00 ha., 14533.00 ha., 3706.00 ha., 1915.00 ha., 25560.00 ha., 194.00 ha., 3596.00 ha., 119056.00 ha., 80787.00 ha., 199843.00 ha., 114689.00 ha. and $193991.00 \mathrm{ha}$. is area under forest, barren cultivated waste, present fallow land, other fallow land, barren and uncultivated land, land put to non-agriculture use, pasture land, area under bush forest \& garden, net sown area, area sown more than once, grass area sown (rabi, kharif, jayad and land prepared for sugarcane), net irrigated area and grass irrigated area respectively. (Source: Land department office and Economics \& Statistics Department Mau 2016-17).

\section{Introduction}

In Indian economy, agriculture and industry are the main sections. Agriculture generates about 14.20 per cent (2016-17) of the total National income. The technological breakthrough in agricultural production took place in the country during 1967-68, brought about a substantial change in income pattern of the farming community. The progressiveness of agriculture will however depend upon what the farmer's do with the additional incomes generated from year to year. The growth rate in the farm economy largely depends on the 
stock of capital built and plans of savings for further improvements to the organization. If the increase in farm income was mostly utilized for increasing capital investment in farm organization, the growth rate in agriculture sector would be higher. If the increasing capital investments were spent on house hold expenditure without building up the necessary infrastructure, the economic development of agriculture might be hampered.

In Indian economy, agriculture and industry are the main sections. Agriculture generates about 14.20 per cent (2016-17) of the total National income. The technological breakthrough in agricultural production took place in the country during 1967-68, brought about a substantial change in income pattern of the farming community. Intensive research efforts are being made to explore new methods and techniques that would further raise agricultural production, increase in incomes and thus savings. As a result the farmers are motivated to save and invest in order to expand their volume of farm business and further raise their income. The progressiveness of agriculture will however depend upon what the farmer's do with the additional incomes generated from year to year. The growth rate in the farm economy largely depends on the stock of capital built and plans of savings for further improvements to the organization. If the increase in farm income was mostly utilized for increasing capital investment in farm organization, the growth rate in agriculture sector would be higher. If the increasing capital investments were spent on house hold expenditure without building up the necessary infrastructure, the economic development of agriculture might be hampered.

Thus the utilization of additional incomes earned by the families as a matter of concern, are in context of rapid economic development of the developing countries. Agricultural development of a country like India is of prime importance, because the majority of the population depends on agriculture as the main source of livelihood. For the development of agriculture sector, the country needs a huge amount of creating the infrastructure in the rural area and for supplying the basic inputs to the farming community. Since it is difficult for any government to meet the requirements of the rural masses for their own resource it becomes necessary to increase the income of the farmers by increasing the productivity of agriculture. An increase in the income of the farmers will increase their saving potentialities, which will ultimately add the capital formation in agriculture. In this connection, the example of Japan and USSR may be cited, where a number of economists have recently begun to emphasize that agriculture should generate surpluses and finance not only its own investments and capital formation but should also help in nonfarm sector.

\section{Materials and Methods}

The methodological aspect has been presented under the following heads.

Sampling Technique

Collection of data and Method of enquiry

Period of enquiry.

Analytical tools

\section{Sampling design}

A two stage random sampling technique was adopted to select the village and farmers while district and blocks was selected purposively to the present study.

\section{Selection of district}

District Mau Nath Bhanjan of U.P. selected purposively because of well acquaintance with the investigator and one of the major crops growing district of eastern U.P. 


\section{Selection of blocks}

There are 09 development blocks are in the district Mau Nath Bhanjan. A list of all the blocks practicing the major crops cultivation was prepared. Out of them 02 blocks namely Ghosi and Kopaganj selected purposively on the basis of highest area under the major crop production.

\section{Selection of the villages}

A list of all the villages falling in selected block, Ghosi and Kopaganj was prepared. Out of them 03 villages from each block was selected randomly. A total of 06 villages would be selected from the universe of the two blocks (Ghosi and Kopagaj) for the investigation.

\section{Selection of sample farmers}

A separate list of farmers of the sample villages was prepared along with their holding size in ascending order.

Farmers from these villages were selected according to size group of holdings. Based on size of holding groups, farms are classified into three groups i.e. (1) Marginal below -1ha, (2) Small 1.0-2.0 ha and (3) Medium 2.0-4.0 ha. A sample of 180 farmers was drawn from the universe of 06 villages ( 90 farmers from the each block) for present investigation.

The number of farmers was selected randomly through proportionate allocation to the population. The number of selected farmers in different villages is given in the table 1 .

\section{Method of enquiry and collection of data}

The present enquiry was conducted by survey method. The primary data were collected from sample farmers through direct personal interview with the help of already prepared and pre-tested schedules. During the period of enquiry, several visits were made to the selected villages and sample farmers for collection of data keeping in view of the convenience of the respondents.

All the possible care was taken in the collection of correct and reliable information through cross checking.

The secondary data were collected from published materials i.e. journals, Books, Bulletins, technical reports etc. and the records of the blocks and District headquarters, Tehsil headquarters and District Information Office, District Statistical Office, records of Lekhapals etc.

\section{Period of study}

The study was pertained for the agricultural year 2017-18.

\section{Analysis of data}

Appropriate statistical tools and techniques such as Tabular analysis, Average, Weightage Average, Benefit-Cost ratio analysis was applied for the testing of present investigation according to the problem in the district Mau Nath Bhanjan.

\section{Statistical Analysis}

Primary data collected was analyzed and tabulated in order to arrive at the results.

In addition mean and percentage were used for the interpretation of the findings.

\section{Tabular analysis}

Tabular analysis was used to compare the values of income, expenditure savings and investment on different categories of households. 


\section{Weighted average}

The average give in the present study refers to the weighted average. It was calculated by using following formula:

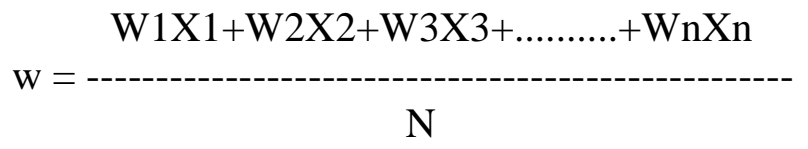

$=\frac{\sum \mathrm{WX}}{\mathrm{N}}$

Where,

$\mathrm{w}=$ Weighted average

$\mathrm{W}_{1}=$ the value of size group (0-1) ha.

$\mathrm{W}_{2}=$ the value of size group (1-2) ha.

$\mathrm{W}_{3}=$ the value of size group (2-4) ha.

$\mathrm{X}_{1}=$ the cultivated area $(0-1)$ ha.

$X_{2}=$ the cultivated area (1-2) ha.

$\mathrm{X}_{3}=$ the cultivated area (2-4) ha.

$\mathrm{N}=$ total cultivated area

\section{Size and composition of family}

The size and composition of family households under study have been given in table 2 .

Table 2 shows that the average size of family of sample farm households came to 5.62 members, which consisted of 1.57 males, 1.33 females and 2.98 children. As regards different size group of farm households, it was a little small being 5.70 members in below 1 hectare size group (marginal farms) as compared to small farms (1-2 hectare size group) and big farms (2-4 hectare size groups) where it worked out to 6.81 and 7.00 members. So far as adult workers was concerned, it came to 2.08 members (1.18 male and 0.90 female workers), which was 2.15 in marginal farms, 2.25 in small farms and 1.25 in big farms. There was found no female worker on big farms because of prestige of the family and use of more hired labour for performing most of the farm operations.

\section{Size of operational holdings}

The number of sample farmers and the area of farm holdings operated by them have been given in table 3 .

The table 3 reveals that the average size of operational land holding on sample farm came to 0.77 hectare. It was 0.47 hectare on marginal farms (below 1 hect. size group) 1.60 hectares on small farms (1-2 hectare size group) and 3.33 hectare on large farms (2-4 hectare size group). The distribution of sample farms and area operated by them shows that marginal farms, large in number cultivated small area while large farms, few in number cultivated comparatively greater area. It indicates the inequitable distribution of the operational land holdings in the study area.

\section{Investment on fixed capital}

The capital investment is an important factor determining the extent of physical and economic resources of the cultivators. Capital investment here refers to investment made by the farmers on items of permanent assets like land, farm building, livestock implements \& machinery and irrigation structure etc. The average value of fixed capital on per hectare and per farm basis has been given in the table 4 and 5 respectively.

As regards investment in fixed capital on per hectare basis it has been given in the table 4 . Table shows that the average investment in fixed assets came to Rs. 218703.57 per hectare. When land value is excluded, it worked out to Rs. 30009.35 on per hectare basis. Of this total investment in land accounted for the highest share being 86.27 
per cent, followed by milch cattle (4.67 per cent), farm building ( 2.78 per cent), irrigation structure (3.02 per cent) and farm implements and machinery (1.92 per cent).

So far as different size groups is concerned. Per hectare total investment in fixed capital showed an increasing trend with the increase in farm size, increasing from Rs. 175545.28 per hectare on marginal farms to Rs. 245861.55 per hectare on small farms and further to Rs. 283195.60 per hectare on big farms. Similarly, investment in fixed capital, excluding land worked out to Rs. 22841.56 per hectare on marginal farms, Rs. 28039.55 on small farms and Rs. 49360.60 per hectare on big farms. This increasing trend in fixed capital investment on big farms was due to their requirements of fixed assets because of large farm business on one hand and better financial position for investment on required assets on the other.

As regards investment on different farm assets, the investment on milch cattle was highest being 6.08 per cent on marginal farms while it was the lowest on all rest items, as compared to small \& big farms. The investment in farm building, implements and machinery and irrigation structure gave an increasing trend with the increase in size of farms because of the reasons as mentioned above. A higher investment on milch animals on marginal farms was that these farmers try to supplement their income by sale of milk, milch and draft castles. Against this situation, the investment on draft cattle was the lowest on all farms because of the use of tractors for completion of different farm operation efficiently in time.

Table 5 reveals that the average total investment in fixed capital worked out to Rs. 168401.74 per farm. When land value is excluded it came to Rs. 23107.19 per farm. A size group wise examination shows that investment in fixed capital gave a great variation amongst different size groups, varying from Rs. 82506.28 on marginal farms to Rs. 393378.48 on small farms and further to Rs. 943041.34 per farm on large farms. This great variation in investment in fixed assets was due to increase in farm size along with increasing size of farm business. Similarly investment excluding land value, varied from Rs. 10735.53 per farm on marginal farm to Rs. 164370.79 on large farms, because of the reasons as mentioned above.

\section{Livestock position}

Livestock constituted 3.94 per cent of the total fixed capital on sample farms of which milch animals accounted for the major share (2.91 per cent). It shows that next to land, livestock is the most important item of capital structure on the farms of study area. As regards the average number of draught and milch cattle per farm and per hectare in different size groups, it has been given in the table 6 .

Table 6 shows that the average number of draught cattle per farm and per hectare came to 0.58 and 0.75 respectively on the sample farms. The number of draught cattle per farm shows an increasing trend with the increase in the size of farms while on per hectare basis a reverse trend was observed. The small number of draught cattle maintained on all farms indicates their lower importance due to use of tractors for completion of major farm operations timely and efficiently.

Against this situation rearing of milch cattle was found a common practice on all size groups of farms. It formed the next important assets of the farmers after land. The number of milch cattle on an average was 1.91 per farm and 2.46 on per hectare basis. Their number gave an increasing trend on per farm basis while a reverse trend was found on per hectare basis. 
Table.1 Selected of farmers from the different village

\begin{tabular}{|c|c|c|c|c|c|c|c|c|c|}
\hline \multicolumn{1}{|c|}{ (A) } & \multicolumn{4}{c|}{ Block - GHOSI } & \multicolumn{4}{c|}{ (B) } & \multicolumn{3}{c|}{ Block - KOPAGANJ } \\
\hline Village & $\begin{array}{c}\text { Below } \\
1 \text { ha. }\end{array}$ & $\begin{array}{c}1-2 \\
\text { ha. }\end{array}$ & $\begin{array}{l}\text { ha. } \\
\end{array}$ & Total & Village & Below & $1-2$ & $2-4$ & Total \\
ha. & & & ha. & \\
\hline MaidapurSamastpur & 25 & 4 & 1 & 30 & Bhanwarkol & 24 & 4 & 2 & 30 \\
\hline Ariyaso & 24 & 3 & 3 & 30 & Chistipur & 26 & 3 & 1 & 30 \\
\hline Bhawanpur & 26 & 3 & 1 & 30 & Hikma & 24 & 5 & 1 & 30 \\
\hline Total & 75 & 10 & 5 & 90 & Total & 74 & 12 & 4 & 90 \\
\hline
\end{tabular}

Table.2 Size and composition of family

\begin{tabular}{|c|c|c|c|c|}
\hline \multirow[t]{2}{*}{ Particulars } & \multicolumn{3}{|c|}{ Size Group (in Hect.) } & \multirow[t]{2}{*}{ Average/Total } \\
\hline & $\begin{array}{l}\text { Below } 1 \\
\text { Hectare }\end{array}$ & $\begin{array}{l}1-2 \\
\text { Hectare }\end{array}$ & 2-4 Hectare & \\
\hline 1. Number of households & 149 & 22 & 9 & 180 \\
\hline 2.Total no. of family member & 849 & 168 & 63 & 1012 \\
\hline I. Male & 230 & 42 & 16 & 284 \\
\hline II. Female & 198 & 38 & 13 & 241 \\
\hline III. Children & 421 & 88 & 34 & 537 \\
\hline $\begin{array}{l}\text { 3.Average size } \text { of } \text { family } \\
\text { (Number) }\end{array}$ & 5.70 & 6.81 & 7.00 & 5.62 \\
\hline I. Male & 1.54 & 1.72 & 1.78 & 1.57 \\
\hline II. Female & 1.33 & 1.36 & 1.44 & 1.33 \\
\hline III. Children & 2.80 & 3.72 & 3.77 & 2.98 \\
\hline $\begin{array}{l}\text { 4. Number of adult workers per } \\
\text { household }\end{array}$ & 2.15 & 2.25 & 1.25 & 2.08 \\
\hline Male & 1.15 & 1.25 & 1.25 & 1.18 \\
\hline Female & 1.00 & 1.00 & - & 0.90 \\
\hline
\end{tabular}

Table.3 Size of operational holding on sample farms

\begin{tabular}{|c|c|c|c|c|}
\hline \multirow[t]{2}{*}{ Particulars } & \multicolumn{3}{|c|}{ Size group (in hectare) } & \multirow[b]{2}{*}{$\begin{array}{l}\text { Average/Tot } \\
\text { al }\end{array}$} \\
\hline & $\begin{array}{l}\text { Below } 1 \\
\text { Hectare }\end{array}$ & 1-2 Hectare & 2-4 hectare & \\
\hline Number of households & 149 & 22 & 9 & 180 \\
\hline $\begin{array}{l}\text { Total cultivated area (in } \\
\text { hectare) }\end{array}$ & 70 & 40 & 30 & 140 \\
\hline $\begin{array}{l}\text { Average size of farm holding } \\
\text { (in hectare) }\end{array}$ & 0.47 & 1.60 & 3.33 & 0.77 \\
\hline Percentage of farm to total & 82.77 & 12.22 & 5.00 & 100 \\
\hline $\begin{array}{l}\text { Percentage of cultivated area } \\
\text { to total }\end{array}$ & 50.00 & 28.57 & 21.43 & 100 \\
\hline
\end{tabular}


Table.4 Investment in fixed capital on sample farms (in Rs. Per hectare)

\begin{tabular}{|c|c|c|c|c|c|}
\hline \multirow{2}{*}{$\begin{array}{l}\text { Sr. } \\
\text { No. }\end{array}$} & \multirow[t]{2}{*}{ Particulars } & \multicolumn{3}{|c|}{ Size Group (in Hectare) } & \multirow[t]{2}{*}{ Average } \\
\hline & & $\begin{array}{l}\text { Below } 1 \\
\text { Hectare }\end{array}$ & 1-2 Hectare & 2-4Hectare & \\
\hline 1 & Land & $\begin{array}{c}152703.71 \\
(86.99)\end{array}$ & $\begin{array}{c}217822.00 \\
(88.59)\end{array}$ & $\begin{array}{c}233835.00 \\
(82.57)\end{array}$ & $\begin{array}{c}188694.21 \\
(86.27)\end{array}$ \\
\hline 2 & Farm building & $\begin{array}{c}3938.922 \\
(2.24)\end{array}$ & $\begin{array}{c}5296.58 \\
(2.15)\end{array}$ & $\begin{array}{c}12169.71 \\
(4.30)\end{array}$ & $\begin{array}{c}6090.56 \\
(2.78)\end{array}$ \\
\hline 3 & Draft animal & $\begin{array}{c}1692.51 \\
(00.96)\end{array}$ & $\begin{array}{c}2524.50 \\
(1.02)\end{array}$ & $\begin{array}{c}3753.00 \\
(1.32)\end{array}$ & $\begin{array}{c}2371.75 \\
(1.08)\end{array}$ \\
\hline 4 & Milch Animal & $\begin{array}{c}10685.42 \\
(6.08)\end{array}$ & $\begin{array}{c}9652.63 \\
(3.92)\end{array}$ & $\begin{array}{c}9872.30 \\
(3.48)\end{array}$ & $\begin{array}{c}10216.10 \\
(4.67)\end{array}$ \\
\hline 5 & Implements \&machinery & $\begin{array}{c}2715.41 \\
(1.54)\end{array}$ & $\begin{array}{c}4897.91 \\
(1.99)\end{array}$ & $\begin{array}{c}6777.10 \\
(2.39)\end{array}$ & $\begin{array}{c}4209.35 \\
(1.92)\end{array}$ \\
\hline 6 & Irrigation structure & $\begin{array}{c}3319.72 \\
(1.89)\end{array}$ & $\begin{array}{c}5225.00 \\
(2.12)\end{array}$ & $\begin{array}{c}16150.74 \\
(5.70)\end{array}$ & $\begin{array}{c}6613.59 \\
(3.02)\end{array}$ \\
\hline \multirow[t]{3}{*}{7} & Miscellaneous & $\begin{array}{l}489.57 \\
(0.27)\end{array}$ & $\begin{array}{c}442.91 \\
(0.18)\end{array}$ & $\begin{array}{l}637.71 \\
(0.22)\end{array}$ & $\begin{array}{c}507.98 \\
(0.23)\end{array}$ \\
\hline & Total including land & $\begin{array}{c}175545.28 \\
(100)\end{array}$ & $\begin{array}{l}245861.55 \\
(100)\end{array}$ & $\begin{array}{c}283195.60 \\
(100)\end{array}$ & $\begin{array}{c}218703.57 \\
(100)\end{array}$ \\
\hline & Total excluding land & 22841.56 & 28039.55 & 49360.60 & 30009.35 \\
\hline
\end{tabular}

Note: Figures in the parentheses shows respecting percentage of total.

Table.5 Investment on fixed capital on sample farms (in Rs. per farm)

\begin{tabular}{|l|l|c|c|c|c|}
\hline \multirow{2}{*}{$\begin{array}{c}\text { Sr. } \\
\text { No. }\end{array}$} & \multicolumn{1}{|c|}{ Particulars } & \multicolumn{3}{|c|}{ Size Group (in Hectare) } & \multirow{2}{*}{ Average } \\
\cline { 3 - 6 } & & $\begin{array}{l}\text { Below 1 } \\
\text { Hectare }\end{array}$ & $\mathbf{1 - 2}$ Hectare & 2-4Hectare & \\
\hline $\mathbf{1}$ & Land & 71770.74 & 348515.20 & 778670.55 & 145294.54 \\
\hline $\mathbf{2}$ & Farm building & 1878.86 & 8474.52 & 40525.13 & 4689.73 \\
\hline $\mathbf{3}$ & Draft animal & 795.47 & 4039.20 & 12497.49 & 1826.24 \\
\hline $\mathbf{4}$ & Milch Animal & 5022.14 & 15444.20 & 32874.75 & 7866.39 \\
\hline $\mathbf{5}$ & Implements \&machinery & 1276.24 & 7836.65 & 22567.74 & 3241.19 \\
\hline $\mathbf{6}$ & Irrigationstructure & 1560.26 & 8360.00 & 53781.96 & 5092.46 \\
\hline $\mathbf{7}$ & Miscellaneous & 230.09 & 708.65 & 2123.75 & 391.14 \\
\hline & Totalincluding land & 82506.28 & 393378.48 & 943041.34 & 168401.74 \\
\hline & Totalexcluding land & 10735.53 & 44863.28 & 164370.79 & 23107.19 \\
\hline
\end{tabular}


Table.6 Number of draught and milch animals by size of farms

\begin{tabular}{|c|c|c|c|c|}
\hline \multirow[t]{2}{*}{ Particulars } & \multicolumn{3}{|c|}{ Size Group (in Hectare) } & \multirow[t]{2}{*}{ Average } \\
\hline & Below 1 Hectare & 1-2 Hectare & 2-4 Hectare & \\
\hline \multicolumn{5}{|c|}{ 1. Draught Cattle } \\
\hline Per farm & 0.40 & 1.27 & 1.88 & 0.58 \\
\hline Per hectare & 0.86 & 0.76 & 0.56 & 0.75 \\
\hline \multicolumn{5}{|c|}{ 2. Total Milch Cattle } \\
\hline Per farm & 1.66 & 2.86 & 3.77 & 1.91 \\
\hline Per hectare & 3.54 & 1.57 & 1.13 & 2.46 \\
\hline \multicolumn{5}{|c|}{ In Dry } \\
\hline Per farm & 1.10 & 1.59 & 2.22 & 1.22 \\
\hline Per hectare & 2.36 & 0.87 & $0 . .67$ & 1.57 \\
\hline \multicolumn{5}{|c|}{ A. Cow } \\
\hline Per farm & 0.77 & 1.09 & 1.55 & 0.85 \\
\hline Per hectare & 1.64 & 0.60 & 0.46 & 1.09 \\
\hline \multicolumn{5}{|c|}{ B. Buffalo } \\
\hline Per farm & 0.33 & 0.50 & 0.04 & 0.37 \\
\hline Per hectare & 0.71 & 0.27 & 0.20 & 0.47 \\
\hline \multicolumn{5}{|c|}{ In Lactation } \\
\hline Per farm & 0.56 & 1.27 & 1.56 & 0.69 \\
\hline Per hectare & 1.19 & 0.70 & 0.44 & 0.89 \\
\hline \multicolumn{5}{|c|}{ A. Cow } \\
\hline Per farm & 0.38 & 0.90 & 1.11 & 0.48 \\
\hline Per hectare & 0.82 & 0.50 & 0.33 & 0.62 \\
\hline \multicolumn{5}{|c|}{ B. Buffalo } \\
\hline Per farm & 0.16 & 0.36 & 0.44 & 0.20 \\
\hline Per hectare & 0.35 & 0.20 & 0.13 & 0.26 \\
\hline
\end{tabular}

Table.7 Source wise irrigation on sample farms (in hectare)

\begin{tabular}{|l|c|c|c|c|}
\hline \multirow{2}{*}{ Particulars } & \multicolumn{3}{c|}{ Size Group (in Hectare) } & \multirow{2}{*}{ Average/Total } \\
\cline { 2 - 4 } & Below 1 Hectare & $\mathbf{1 - 2 ~ H e c t a r e}$ & 2-4 Hectare & \\
\hline Canal & 3.00 & 1.00 & 0.50 & 4.50 \\
\hline Tube wells & $(4.38)$ & $(2.56)$ & $(1.75)$ & $(3.30)$ \\
\hline Other sources & 65.50 & 38.00 & 28.00 & 132.50 \\
\hline Total irrigated area & $(95.62)$ & $(97.43)$ & $(98.25)$ & $(96.70)$ \\
\hline Total cultivated area & - & - & - & - \\
\hline Percentage of irrigated area to & 68.50 & 39.00 & 28.50 & 136.00 \\
total cultivated area & $(100)$ & $(100)$ & $(100)$ & $(100)$ \\
\hline
\end{tabular}

Note: Figures in the parentheses shows respecting percentage of total. 
Table.8 Major crops grown by sample farms and area of different crops

\begin{tabular}{|c|c|c|c|c|c|}
\hline \multirow{2}{*}{\multicolumn{2}{|c|}{ Particulars }} & \multicolumn{3}{|c|}{ Size Group (in Hectare) } & \multirow{3}{*}{$\begin{array}{l}\text { Total } \\
90.25 \\
(37.80)\end{array}$} \\
\hline & & Below 1 Hectare & 1-2 Hectare & 2-4 Hectare & \\
\hline 1. & Paddy & $\begin{array}{c}46.50 \\
(39.20)\end{array}$ & $\begin{array}{c}23.75 \\
(34.70)\end{array}$ & $\begin{array}{c}20.00 \\
(38.83)\end{array}$ & \\
\hline 2. & Wheat & $\begin{array}{c}52.75 \\
(44.45)\end{array}$ & $\begin{array}{c}26.50 \\
(38.70)\end{array}$ & $\begin{array}{c}22.50 \\
(43.70)\end{array}$ & $\begin{array}{l}101.75 \\
(42.63)\end{array}$ \\
\hline 3. & Arhar & $\begin{array}{c}2.35 \\
(2.00)\end{array}$ & $\begin{array}{l}2.00 \\
(2.91)\end{array}$ & $\begin{array}{c}1.90 \\
(3.70)\end{array}$ & $\begin{array}{c}6.25 \\
(2.61)\end{array}$ \\
\hline 4. & Maize & $\begin{array}{c}2.55 \\
(2.15)\end{array}$ & $\begin{array}{c}3.50 \\
(5.10)\end{array}$ & $\begin{array}{c}1.20 \\
(2.33)\end{array}$ & $\begin{array}{c}7.25 \\
(3.03)\end{array}$ \\
\hline 5. & rapeseed \& mustard & $\begin{array}{c}7.80 \\
(6.57)\end{array}$ & $\begin{array}{c}7.50 \\
(11.00)\end{array}$ & $\begin{array}{c}4.50 \\
(8.73)\end{array}$ & $\begin{array}{l}19.80 \\
(8.30)\end{array}$ \\
\hline & Other crops & $\begin{array}{c}6.75 \\
(5.70)\end{array}$ & $\begin{array}{c}5.25 \\
(7.66)\end{array}$ & $\begin{array}{c}1.40 \\
(2.71)\end{array}$ & $\begin{array}{r}13.40 \\
(5.61)\end{array}$ \\
\hline & al cropped Area & $\begin{array}{c}118.70 \\
(100)\end{array}$ & $\begin{array}{l}68.50 \\
(100)\end{array}$ & $\begin{array}{l}51.50 \\
(100)\end{array}$ & $\begin{array}{c}238.70 \\
(100)\end{array}$ \\
\hline & cultivated area & 70.00 & 40.00 & 30.00 & 140.00 \\
\hline
\end{tabular}

Note: Figures in the parentheses shows respecting percentage of total.

Table.9 Intensity of cropping on sample farms

\begin{tabular}{|l|l|c|c|c|c|}
\hline \multicolumn{2}{|c|}{ Particulars } & \multicolumn{3}{c|}{ Size Group (in Hectare) } & Average/Tota \\
\cline { 3 - 5 } & $\begin{array}{c}\text { Below 1 } \\
\text { Hectare }\end{array}$ & $\begin{array}{c}\mathbf{1 - 2} \\
\text { Hectare }\end{array}$ & $\mathbf{2 - 4}$ Hectare & I \\
\hline 1. & Cultivated Area(in hectare) & 70.00 & 40.00 & 30.00 & 140.00 \\
\hline 1 & Cropped Area(in hectare) & 118.70 & 68.50 & 51.50 & 238.70 \\
\hline 3. & $\begin{array}{l}\text { Intensity of Cropping(In } \\
\text { percent) }\end{array}$ & 169.60 & 171.25 & 171.66 & 170.50 \\
\hline
\end{tabular}

\section{Source wise irrigated area}

Irrigation is the one important factor of agricultural production, determining the productivity and kinds of crops to be grown, use of input resources and intensity of cropping. The extent of irrigated area of different sources on sample farms has been given in the table 7 . Table 7 shows that irrigated area to cultivated area on sample farms came to 97.14 per cent, which was a little higher being 97.86 per cent on marginal farms as compared to 97.50 on small farms and 95.00 per cent on large farms.
The main sources of irrigation were canals and tube wells which irrigated 3.30 per cent and 96.70 per cent respectively of the total irrigated area. As regards different size groups, the area irrigated by tube well gave an increasing trend with the increase in size of farms while a reverse trend was observed in area irrigated by canals where it was higher on marginal farms as compared to large farms where it came higher by tube wells. It was due to tube wells irrigation facilities available on large farms on one hand and capacity for payment of tube wells irrigation expenses on the other. 


\section{Cropping Pattern}

The progressiveness of the farm is highly determined by the cropping pattern followed on the farm which is mainly influenced by the size of holding, source of irrigation, level of inputs and availability of labour etc. It ultimately determines the level of income and employment on the farm.

It is evident from cropping pattern of the sample farms (Table 7) that paddy, wheat, maize and rapeseed and mustard etc. were the main crops grown on sample farms. Amongst different crops wheat accounted for the highest average share being 42.63 per cent, followed by paddy 37.80 per cent, Rapeseed $\&$ mustard 8.30 per cent, maize 3.03 per cent and arhar 2.61 per cent to total cropped area of sample farm.

\section{Intensity of cropping}

The intensity of cropping is an important index for measuring the efficiency of a farm. Higher the intensity of cropping, generally higher would be the employment and income on the farm.

The intensity of cropping was worked out by using the following formula:

Total cropped area

$\begin{aligned} \text { Intensity of cropping = ----------------- x } 100 & \text { Net sown area }\end{aligned}$

Table 8 shows that the average intensity of cropping on sample farms came to 170.50 per cent. It was a little higher on large farms (171.66 per cent) as compared to small farms (171.25 per cent) and marginal farmers (169.60 per cent).

The structural analysis of the sample farms showed that the study area is dominated by small farm holdings. The average size of operational farm holding came to 0.77 hectare. It was 0.0.47 hectare for marginal farms of below 1 hectare size group, 1.60 hectare for small farms of 1-2 hectare size group and 3.33 hectares for medium farms of 2-4 hectare size group of farms. The marginal farmers who constituted 82.77 per cent of the total was cultivating 50.00 per cent of the total cultivated area while the medium farmers who accounted for 5.00 per cent only in total, were cultivating 21.43 per cent of the total cultivated area under study. It shows the inequitable distribution of operational holdings in the study area.

The average size of family of the sample farms came to 7.14 members. It was a little small being 5.70 members on marginal farms as compared to 6.81 members on small farms and 7.00 members on medium farms. As regards number of adult workers, the average number came to 2.08 . It was higher being 2.25on small farms but lower on marginal farms being 2.15 as compared to medium farms where it was 1.25 workers only. The lower number of adult workers on medium farms was due to no female workers because of prestige of the family and use of more hired labour.

The average investment in fixed capital including land on per farm household basis came to Rs. 145294.54 , which varied from Rs. 71770.74 on marginal farms to Rs. 348515.20 on small farms and further to Rs. 778670.55 per farm on medium farms. When land is excluded, the average investment in fixed capital worked out to Rs.23107.19 per farm. It showed an increasing trend with the increase in farm size, increasing from Rs. 10735.53 to Rs. 164370.79 per farm on different size group of farms. This increasing trend in investment of fixed capital was due to increasing trend in size of farm business and investment capacity of the medium farmers according to their requirements of farms 
business. Amongst different assets, land accounted for the highest share being 86.27 per cent, followed by livestock 5.75 per cent, irrigation structure 3.02 and farm buildings 2.78 per cent 1.92 per cent to total capital investment. As regards different size groups, investment on milch animals was 6.08 per cent on marginal farms while 3.92 and 3.48 per cent to small and medium farms respectively. Similar trend was seen on irrigation structure, implements \& farm machinery but in farm buildings, it was an increasing trend from marginal to large farms. The investment in draft cattle was the lowest on all farms due to use of advance machinery.

The analysis of cropping pattern showed that Paddy, Wheat, Arhar, Maize and Rapeseed \& Mustard were the main crops grown by the sample farmers. Amongst these, wheat accounted for the highest area being 42.63 per cent, followed by paddy 37.80 per cent, rapeseed and mustard 8.30 per cent, maize 3.03 per cent and arhar 2.61 per cent and to total cropped area.

The area under paddy, wheat, arhar and rapeseed \& mustard gave a decreasing trend with the increase in farm size. Maize was higher on small farms followed by marginal and medium farms.
The main source of irrigation in the area were tube wells and canal which on an average irrigated 96.70 per cent and 3.30 per cent of the total irrigated area. The area irrigated by canal was higher on marginal farms and gave a declining trend with the increase in farm size. Against this situation, the area irrigated by tube wells gave an increasing trend with the rise in farm size because medium farmers were having their own tube wells and depended less on canal irrigation.

The average intensity of cropping on farms came to 170.50 per cent which was a little lower being 169.60 per cent on marginal farms and a little higher 171.77 on medium farms.

\section{References}

Devi, G. and Singh, Y. C. (2015). Resource use and technical efficiency of rice production in Manipur. International Journal of Development Research. 5(5): 4403-4411

Reddy, Dr. E. L. and Reddy, Dr. D. R. (2013). A study on resource use efficiency of input factors with reference to farm size in paddy cultivation in Nellore district. IOSR Journal Of Humanities and Social Science. 17(1): 48-55.

\section{How to cite this article:}

Kuldeep Maurya, J. Rai, Sharad Yadav, Ram Singh Yadav and Arun Kumar Rajbhar. 2019. Aneconomic Study the Resource Structure and Levels of Investment on the Sample Farms in District of Mau Nath Bhanjan (U.P.), India. Int.J.Curr.Microbiol.App.Sci. 8(08): 1234-1244. doi: https://doi.org/10.20546/ijcmas.2019.808.145 